\title{
The Role Of Organizational Citizenship Behavior In Work Performance: An Investigation Based On Hotel Employee Survey
}

\author{
Reynaldi Reynaldi, Syamsul Ridjal, and Herman Sjahruddin
}

\begin{abstract}
This study aims to analyze the role of organizational citizenship behavior in explaining the influence of organizational support and work environment on employee work performance at the Grand Asia Hotel Makassar. The sampling method used is non-probability sampling that is 77 respondents. The analysis used in hypothesis testing is Structural Equation Modeling (SEM) with the help of WarpPLS Software version, 6.0. The results of this study indicate that organizational support has a positive and significant effect on organizational citizenship behavior, work environment has a positive and significant effect on organizational citizenship behavior, organizational citizenship behavior, organizational support has a positive and significant effect on employee work performance, the work environment has a positive and not significant effect on employee work performance, organizational support has a positive and significant effect on employee work performance mediated by organizational citizenship behavior, work environment has a positive and significant effect on employee work performance mediated by organizational citizenship behavior. In this study organizational citizenship behavior is proven to be a mediating variable.
\end{abstract}

Index Terms-OCB, organizational support, work environment, work performance

\section{INTRODUCTION}

The development of the tourism industry involves a variety of businesses, one of which is the hospitality business. Hotels are commercial businesses that provide lodging accommodations, meeting rooms and other services to the public. A hotel is an organization engaged in services with the focus of its activities is to serve hotel guests through quality service. Hotels are required to have the best form of service to be offered to hotel guests so that hotel guests choose their services [1]. The hotel industry in Makassar City is very high in competition intensity, so hotel management is demanded to increase all of its resources including creating high quality human resources who have high work performance. This is caused by the role of labor or human resources that can influence the development of hotels and play a role in carrying out hotel activities [2]. The success of the hospitality industry in winning business competition can be seen from, one of them through the work

Published on November 24, 2019

R.R., School of Economics in Makassar (STIEM Bongaya), Indonesia. (e-mail: reynaldhy.pratama@yahoo.com)

S.R , School of Economics in Makassar (STIEM Bongaya), Indonesia. (e-mail: ridjalsyamsu@yahoo.com)

H.S , School of Economics in Makassar (STIEM Bongaya), Indonesia. (e-mail: herman.sjahruddin@stiem-bongaya.ac.id) performance produced by its employees. Work performance is the result of quality and quantity of work achieved by an employee in carrying out their duties in accordance with the responsibilities given to him [3].

One of the hospitality services that are in great demand by foreign and domestic tourists, due to its strategic location in Makassar City in the past 5 years is the Grand Asia Hotel Makassar, which is one of the 3 star hotels in Makassar, but in the last 2 (two) years (2018 -2019) according to the facts of the field shows that the occupancy rate of hotel rooms which are the main source of income of the hotel tends to decrease (the total number of hotel rooms is 138 rooms, but only about 80 rooms are used every month). One of the factors that influenced the decrease in room occupancy rate was due to the low work performance produced by employees, which employees have not been able to continuously innovate in hospitality and hospitality service marketing. In addition, evidence was also found that some employees who excel in work expect organizational support in the form of career advancement (promotion) but the hotel management has not been able to fulfill it so that it is the cause of decreased employee performance. Job performance in English is called work performance or performance, which is defined as "performance is defined as the record of outcomes produced on a specified job function or activity during a specified time period" which can be interpreted as a record of the results obtained through certain job functions or activities during a certain time [4].

Based on the theory, high or low work performance is influenced by ability multiplied by the effort that is effort and support. The theory explains that abilities are abilities possessed by employees which in this study are shown through voluntary or helping behavior (Organizational Citizenship Behavior). Whereas for support is shown through organizational support (leaders and colleagues), then for effort is shown through the work environment that is the effort of members of the organization to create a good organizational environment [5]. The theory is the same with the statement, that psychologically perceived organizational support at a high level raises three things in employees, namely, the creation of reciprocal relationships, creating a feeling of obligation to care for the safety of the organization and help the organization to achieve its goals and awareness of recognition and respect for the organization of employees and strengthen employee confidence that the organization recognizes and appreciates employee performance, the greater the award given by the organization [6]. This statement is in line with the findings of previous researchers that the higher the support provided by the organization, the higher the work performance generated by employees [7]. However, these findings have 
been denied by other researchers, that organizational support has a negative and not significant effect on employee performance which in this study is reflected by employee work performance [8].

Other factors that affect employee work performance are shown in work environment factors. Work environment is a situation around the workplace both physically and nonphysically which can give the impression of being pleasant, secure, and appealing [9]. Organizations need a good work environment to keep employees in the company [2]. The statement is in line with the findings of previous researchers, that the work environment has a positive and significant effect on employee work performance [10]. These findings have been denied by other researchers, the work environment has a negative and not significant effect on work performance [11].

There are inconsistencies in the findings in analyzing the influence of organizational support and work environment, so researchers try to Organizational Citizenship Behavior (OCB) as a mediator. Organizational Citizenship Behavior is very important to be raised by employees, because this behavior is voluntary that comes from within the employee who can help the organization and employees in producing high work performance. Organizational Citizenship Behavior (OCB) is employee behavior that exceeds the mandatory role, which is not directly or explicitly recognized by the formal reward system and or preferred behavior that is not part of an employee's formal work obligations, but supports the functioning of the organization effectively [12]. The results of previous studies provide evidence that Organizational Citizenship Behavior (OCB) has a positive and significant effect on employee performance which in this study is reflected by work performance [13]. The results of the study are relevant to the findings of other researchers, that the better the OCB employee's behavior, the higher the employee's work performance [14].

In addition to the above research results, there are also results of research on Organizational Citizenship Behavior (OCB) which in this study act as mediating variables, based on research findings, that the higher organizational support will increase OCB employees which will have an impact on improving employee performance which in this study is reflected by employee performance [15]. The better the organizational environment of employees, the more improved Organizational Citizenship Behavior in employees will have an impact on improving employee work performance which in this study is reflected by employee performance $[16,17]$.

\section{LITERATURE REVIEW}

\section{A. Work achievement}

Survival of an organization depends on the work performance of employees in carrying out their work in achieving company goals. Achievement of organizational goals becomes less effective if many employees are not performing, Achievement is the work of quality and quantity achieved by an employee in carrying out their duties in accordance with the responsibilities given to him [3]. Furthermore, performance appraisal is a tool to measure the quality of the human resources of the organization. With the performance appraisal, the leader can find out the overall conditions of employee performance. Performance appraisal is the process through which organizations evaluate or assess work performance [18]. With this assessment we can find out how the level of the employees reached the job requirements.

Work performance is also defined as performance is defined as the record of outcomes produced on a specified job function or activity during a specified time period. Job performance is defined as a record of the results obtained through certain job functions or activities over a certain period of time [4]. Based on his theory, work performance or individual performance proposed, that performance $(\mathrm{P})$ is the result of ability is a multiplied by effort $(\mathrm{E})$, multiplied by support $(\mathrm{S}), \mathrm{P}=\mathrm{A} \times \mathrm{E} \times \mathrm{S}$. In the theory explains the high or low work performance is influenced by the ability is a multiplied by the effort being expended and support [5]. The theory explains that abilities are abilities possessed by employees which in this study were demonstrated through voluntary or helping behavior (OCB). Whereas for support (support) is shown through organizational support (leadership and coworkers), then for ability (ability) is shown through the work environment that is the ability of members of the organization to create a good organizational environment.

There are fives dimensions of work performance measurement, namely: (1) Work quality, namely the quality or work quality achieved based on the conditions of suitability and readiness, (2) Quantity of work, namely the amount of work carried out in a period of time determined by the company, (3) Consistency is the ability to continuously improve the skills and knowledge possessed, (4) Cooperation is the ability and willingness to cooperate with fellow members of the organization, (5) Attitudes namely the ability to obey rules and employee loyalty in carrying out work [3].

\section{B. Organizational support}

Organizational support is the support received from the organization in the form of training, equipment, expectations and productive work teams $[5,19]$. Organizational support is assistance from the application of technology; humans carry out functions or tasks that lead to the achievement of rationally determined goals [19]. There are 3 general forms of organizational treatment that employees expect to be received from the organization [6]. These three things are: (1) Justice, Justice in question, is related to the fair distribution of resources among employees. Justice is divided into two structural aspects and social aspects. Structural aspects are defined as formal rules and policies that affect employees [4]. For example, notice before the implementation of a policy, receipt of accurate information, participation of employee opinions, (2) Supervisor support, Just as employees form their general perceptions regarding the organization's appreciation of them, they also develop a general view regarding how much supervisors appreciate their contribution and care towards their welfare. The employees as agents of the organization have the responsibility to direct and evaluate the performance of their subordinates. (3) Organizational rewards and working conditions, human resource practices that show recognition of employee contributions. These practices are: First, recognition, payment and promotion. Favorable rewards for employees, used to communicate positive ratings on 
employee contributions. Second, the job security is a guarantee that the organization hopes to maintain the employee's future membership. Finally, the role stressors. The cause of stress refers to the situation of environmental needs that cannot be overcome by employees. Such as excessive workload, role ambiguity, role conflict.

There are four characteristics / dimensions of organizational support [20] are as follows: (1) Awards, companies giving awards or rewards for employee work performance. (2) Development, the company pays attention to capabilities and provides training and promotion opportunities for employees. (3) Working conditions, regarding the workplace environment of employees, (4) Employee welfare, the company cares about the welfare of employees' lives.

\section{Work environment}

Work environment is a condition around the workplace both physically and non-physically that can give the impression of being pleasant, secure, and appealing [21]. The work environment is divided into two parts, namely the physical work environment and the non-physical work environment [9]. (1) Physical work environment is all physical conditions in the vicinity of the workplace that can affect employees both directly and indirectly, (2) Nonphysical work environment is all conditions relating to work relationships (relationships with superiors and fellow relationships coworkers) and pressures within the scope of the organization that can affect the conditions of employees' physiology and psychology at work.

Measurement of the physical work environment consists of four dimensions [22], namely: (1) Workplace buildings, Workplace buildings in addition to being attractive are also built with consideration of work safety, so that employees feel safe in doing their work, (2) Adequate work equipment, Adequate equipment is needed by employees because it will support employees in completing tasks they carry out in the company, (3) Facilities, company facilities are needed by employees as supporters in completing work in the company for example such as Internet connection. In addition there are things that need to be considered by the company namely on how to humanize employees, such as the availability of facilities for employees to rest after being tired of working and also the availability of places of worship, (4) The availability of transportation facilities, the availability of transportation facilities will support both employees intended for employees and manager. Where, the employees use transportation to carry out operational activities, while managers benefit from special activities such as meeting important clients.

\section{Organizational citizenship behavior}

Organizational Citizenship Behavior (OCB) is free individual behavior, which is not directly or explicitly recognized by the reward system and in promoting the effective functioning of the organization. In other words, OCB is employee behavior that exceeds the mandatory role, which is not directly or explicitly recognized by the formal reward system. It is an optional behavior that is not part of an employee's formal work obligations, but supports the effective functioning of the organization [23]. There are seven dimensions of Organizational Citizenship Behavior, [16,24], namely: (1) Sportsmanship, is the willingness or desire of employees to tolerate the inconveniences that arise and the determination of work without complaints. (2) Civic virtue is an employee commitment to the company as a whole such as attending meetings, expressing opinions, or actively participating in company activities. (3) Helping behavior is the voluntary behavior of employees to help colleagues or prevent problems related to work. (4) Organizational loyalty is a form of employee loyalty towards the company such as displaying a positive image about the company, defending the company from external threats, and supporting and defending the goals of the organization. (5) Organizational compliance is the behavior of employees who comply with all rules, procedures, and regulations of the organization even though there is no party to supervise. (6) Individual initiative is a form of encouragement from within employees to carry out tasks better or exceed established standards. (7) Self development is the behavior of employees voluntarily to improve knowledge, skills their own and abilities, such as taking courses, training, seminars, or following the latest developments from the mastered field.

\section{RESEARCH METHOD}

The population in this study was all employees of Grand Asia Hotel Makassar, amounting to 77 people. The sampling technique using a non probability sampling. Based on this the samples in this study were all employees of Grand Asia Hotel Makassar, amounting to 77 employee. Data analysis using variance-based SEM (SEM-PLS) using WarpPLS 6.0.

\section{RESEARCH RESUltS}

\section{A. Respondents}

Respondent characteristics in the form of gender, age, years of service, education and marital status are presented to find out the number of frequencies and percentages of the presence of respondents who were representative in providing responses. Shown as follows:

\begin{tabular}{llcc}
\multicolumn{2}{c}{ TABLE I: RESPONDENTS } \\
\multicolumn{2}{c}{ Respondent Characteristics } & $\begin{array}{c}\text { Frequency } \\
(n=123)\end{array}$ & $\begin{array}{c}\text { Percent } \\
(\%)\end{array}$ \\
\hline \multirow{2}{*}{ Gender } & Men & 55 & 71.4 \\
& Women & 22 & 28.6 \\
& $20-30$ & 54 & 70.1 \\
Ages & $31-40$ & 12 & 15.6 \\
& $41-50$ & 6 & 7.8 \\
Working & $>51$ & 5 & 6.5 \\
experiences & 1 to 2 Years & 23 & 29.9 \\
& 3 to 4 Years & 32 & 41.6 \\
Level of & High School/ & 22 & 28.6 \\
education & equivalent & 25 & 32.5 \\
& Diploma & & \\
& Bachelor & 12 & 15,6 \\
Marital & Not Married & 40 & 51.9 \\
Status & Married & 50,5 & 64.9 \\
& Widowed & 26 & 33.8 \\
& & 1 & 1.3
\end{tabular}

The table shows that the employees who work at the Grand Asia Hotel Makassar are male; this condition is caused because the company is engaged in hospitality 
services which are more dominant in need of personnel men's work to provide 24-hour services to guests of Grand Asia Hotel Makassar, which in this study was dominated by men by $71.4 \%$. The average age of employees is $20-30$ years at $70.1 \%$ with a working period of 1 to 2 years, this condition is seen in this company as being still dominant as a productive age. The education level of respondents is considered quite well with a dominant Bachelor as much as $51.9 \%$ with the status of unmarried marriage of $64.9 \%$.

\section{B. Variable Goodness of fit}

The p-value for the average path coefficient (APC) and the ARS and the R-squared value Average (ARS) must be $<0.05$ or significant meaning. In addition, the average full collinearity VIF (AFVIF) as an indicator of multicollinearity must be $<5$. For this it can be shown in following the table: Table 2. Goodness of fit

\begin{tabular}{ll}
\multicolumn{1}{c}{ Table 2. Goodness of fit } & \\
\hline \multicolumn{1}{c}{ Measurement } & Value \\
\hline Average path coefficient (APC) & $0.380 \rightarrow \mathrm{P}=<0.001$ \\
Average R-squared (ARS) & $0.844 \rightarrow \mathrm{P}=<0.001$ \\
Average adjusted R-squared (AARS) & $0.839 \rightarrow \mathrm{P}=<0.001$ \\
Average block VIF (AFVIF) & $\begin{array}{l}4.607, \text { acceptable if } \\
<=5, \text { ideally }<=3.3\end{array}$ \\
\hline
\end{tabular}

Table 2 shows that the overall measures in explaining the feasibility of the model (Goodness of fit has met the required criteria, that the results of the model conformity test (Goodness of fit model) have been met, that the Average path coefficient (APC), Average R-squared (ARS), and Average adjusted R-squared (AARS) has p-value $=<0.05$ and Average full collinearity VIF (AFVIF) as an indicator of multicollinearity has a value $<5[25,26]$.

\section{Validity and reliability construct}

Measurement models or outer models namely construct validity and reliability. This output is used by researchers to report the results of convergent validity testing of measurement instruments (questionnaires). In Table 3 Combined Loading and cross-loadings there are no constructs that do not meet the standard with convergent validity $>0.70$, so that it causes no indicators to be excluded from the model $[25,26]$.

Table 3. Combined Loading and cross-loadings

\begin{tabular}{lcccc}
\hline \multicolumn{1}{c}{ Model } & DO & LK & OCB & PK \\
\hline $\mathrm{X}_{11}$ & 0.823 & -0.133 & 0.623 & -0.280 \\
$\mathrm{X}_{12}$ & 0.878 & 0.494 & -0.005 & -0.509 \\
$\mathrm{X}_{13}$ & 0.850 & -0.282 & -0.524 & 0.332 \\
$\mathrm{X}_{14}$ & 0.855 & -0.099 & -0.074 & 0.462 \\
$\mathrm{X}_{21}$ & 0.379 & 0.845 & -0.083 & -0.021 \\
$\mathrm{X}_{22}$ & 0.213 & 0.845 & 0.262 & -0.785 \\
$\mathrm{X}_{23}$ & -0.050 & 0.851 & -0.356 & 0.368 \\
$\mathrm{X}_{24}$ & -0.545 & 0.842 & 0.180 & 0.437 \\
$\mathrm{Y}_{11}$ & 0.282 & -0.409 & 0.855 & 1.389 \\
$\mathrm{Y}_{12}$ & 0.054 & 0.317 & 0.867 & -1.786 \\
$\mathrm{Y}_{13}$ & -0.369 & -0.598 & 0.726 & 2.549 \\
$\mathrm{Y}_{14}$ & 0.016 & 0.415 & 0.882 & -0.956 \\
$\mathrm{Y}_{15}$ & 0.236 & 0.383 & 0.795 & -1.199 \\
$\mathrm{Y}_{16}$ & 0.054 & 0.317 & 0.867 & -1.786 \\
$\mathrm{Y}_{17}$ & -0.369 & -0.598 & 0.726 & 2.549 \\
$\mathrm{Y}_{21}$ & 0.343 & -0.335 & -0.884 & 0.856 \\
$\mathrm{Y}_{22}$ & 0.221 & 0.214 & 0.284 & 0.865 \\
$\mathrm{Y}_{23}$ & -0.338 & -0.538 & -0.895 & 0.751 \\
$\mathrm{Y}_{24}$ & -0.214 & 0.239 & 0.682 & 0.859 \\
$\mathrm{Y}_{25}$ & -0.060 & 0.385 & 0.767 & 0.780 \\
\hline
\end{tabular}

\section{Discriminant validity}

The discriminant validity test is the degree to which the measurement results of a concept are able to distinguish themselves from the measurement results of other concepts theoretically must be different [26.27]. Discriminant validity is also part of the outer model. The requirement to fulfill this discriminant validity requirement is that the results in view combined loading and cross-loadings show that loading to other constructs (cross-loading) is lower than loading to the variable construct.

Table 4. Discriminant Validity

\begin{tabular}{lcccc}
\hline Model & DO & LK & OCB & PK \\
\hline $\mathrm{X}_{11}$ & 0.823 & -0.133 & 0.623 & -0.280 \\
$\mathrm{X}_{12}$ & 0.878 & 0.494 & -0.005 & -0.509 \\
$\mathrm{X}_{13}$ & 0.850 & -0.282 & -0.524 & 0.332 \\
$\mathrm{X}_{14}$ & 0.855 & -0.099 & -0.074 & 0.462 \\
$\quad \mathrm{X}_{21}$ & 0.379 & 0.845 & -0.083 & -0.021 \\
\multicolumn{1}{c}{$\mathrm{X}_{22}$} & 0.213 & 0.845 & 0.262 & -0.785 \\
\multicolumn{1}{c}{$\mathrm{X}_{23}$} & -0.050 & 0.851 & -0.356 & 0.368 \\
\multicolumn{1}{c}{$\mathrm{X}_{24}$} & -0.545 & 0.842 & 0.180 & 0.437 \\
$\mathrm{Y}_{11}$ & 0.282 & -0.409 & 0.855 & 1.389 \\
$\mathrm{Y}_{12}$ & 0.054 & 0.317 & 0.867 & -1.786 \\
$\mathrm{Y}_{13}$ & -0.369 & -0.598 & 0.726 & 2.549 \\
$\mathrm{Y}_{14}$ & 0.016 & 0.415 & 0.882 & -0.956 \\
$\mathrm{Y}_{15}$ & 0.236 & 0.383 & 0.795 & -1.199 \\
$\mathrm{Y}_{16}$ & 0.054 & 0.317 & 0.867 & -1.786 \\
$\mathrm{Y}_{17}$ & -0.369 & -0.598 & 0.726 & 2.549 \\
\multicolumn{1}{r}{$\mathrm{Y}_{21}$} & 0.343 & -0.335 & -0.884 & 0.856 \\
$\mathrm{Y}_{22}$ & 0.221 & 0.214 & 0.284 & 0.865 \\
$\mathrm{Y}_{23}$ & -0.338 & -0.538 & -0.895 & 0.751 \\
$\mathrm{Y}_{24}$ & -0.214 & 0.239 & 0.682 & 0.859 \\
$\mathrm{Y}_{25}$ & -0.060 & 0.385 & 0.767 & 0.780 \\
\hline
\end{tabular}

The table shows that the discriminant validity has been fulfilled, as indicated by the loading value to other constructs is lower than the value of loading to the construct itself in the same column.

\section{E. Reliability construct}

The test results Reliability constructs can be shown by the output latent variable coefficient, as in the following table:

Table 5. Latent variable coefficient

\begin{tabular}{lcccc}
\multicolumn{1}{c}{ MODEL } & DO & LK & OCB & PK \\
\hline R-Squared & & & 0778 & 0909 \\
Composite Reliability & 0914 & 0910 & 0934 & 0913 \\
Cronbach's Alpha & 0874 & 0867 & 0917 & 0880 \\
Avg. Var. Extrac. & 0.725 & 0.715 & 0.671 & 0.678 \\
Full Collin. VIF & 3,619 & 3,461 & 7,671 & 9793 \\
Q-Squared & & & 0.775 & 0.907 \\
\hline
\end{tabular}

The coefficient of determination (R-squared) that shows what percentage of the variance of the construct of an endogenous / criterion can be explained by the construct of the hypothesized effect. The higher R-squared shows a good model. From the results of the latent variable coefficient output shows the R-squared of 0.909 means that the 
variance of work performance can be explained by $91 \%$ by the variance of organizational support, work environment and organizational citizenship behavior. The composite reliability and Cronbach alpha values fulfill the reliability requirements $>0.70$. The above output also shows that the average variance extracted $(\mathrm{AVE})>0.50$ which means that it has met the requirements of convergent validity $[25,26]$. Qsquared is a non-parametric measure obtained through the algorithm blindfolding and is used to study the predictive validity or relevance of a set of predictor latent variables on the criterion variable. The output shows Q-squared is greater than zero that is 0.907 , it means that the estimation of the model shows good predictive validity. Broadly speaking, the results of the measurement model (outer model) of the reflective construct have fulfilled the requirements [26,27].

\section{F. Hypothesis testing}

The results of testing the models and hypotheses show that, among the seven causality between variables (direct influence) built in this model, there is one causality between variables in the rejected direct effect test, namely the work environment with $\mathrm{p}$-value $=0.106>0.05$.

Table 6. Path coefficient and p-value

\begin{tabular}{lcccccc}
\hline \multicolumn{3}{c}{ Path Coefficient } & \multicolumn{3}{c}{ P Values } \\
\hline Variable & DO & LK & OCB & DO & LK & OCB \\
OCB & 0.608 & 0.302 & & $<0.001$ & 0.002 & \\
PK & 0.215 & 0.138 & 0.635 & 0.024 & 0.106 & $<0.001$ \\
\hline \multicolumn{2}{l}{ Indirect effect } & & & & & \\
\hline PK & 0.386 & 0.192 & & $<0.001$ & 0.007 & \\
\hline
\end{tabular}

G. Organizational support has a positive significant effect on organizational citizenship behavior (OCB) employees

The contribution of organizational support on organizational citizenship behavior can be proven by the standardized path coefficient (beta / standardized path coefficient) of 0.608 with a positive direction. Beta / standardized path coefficient marked positive explains that organizational support is at a high level, with p-value = $<0.001<0.05$ explains that organizational support is at a high level so that it can make a real contribution to improving organizational citizenship behavior of employees. Hypothesis testing results prove that organizational support has a significant positive effect on organizational citizenship behavior of employees, so that the hypothesis proposed $\left(\mathrm{H}_{1}\right)$ that organizational support significant positive effect on organizational citizenship behavior (OCB) employees declared accepted or supported by empirical facts. The positive significant contribution of organizational support to organizational citizenship behavior of employees is due to the provision of development in the form of training to employees in accordance with the field of work so as to increase and enhance the skills or abilities of employees in carrying out their duties and responsibilities properly and correctly. Providing training is also carried out not only according to the field being worked on but also given training on other units of the field of work or carried out (cross training) so that employees have additional knowledge outside the field being worked on. This additional knowledge causes voluntary attitudes (OCB) for employees to perform tasks outside of their responsibilities in terms of helping among colleagues
H. Work environment has a positive significant effect on organizational citizenship behavior employees

The contribution of the work environment to organizational citizenship behavior of employees can be proven by the standardized path coefficient (beta / standardized path coefficient) of 0.302 with a positive direction. Beta / standardized path coefficient is positive signifying that the work environment is at a high level with p-value $=0.002<0.05$ explaining that the work environment is at a high level so that it can make a real contribution to improving organizational citizenship behavior employee. Hypothesis testing results prove that the work environment significant positive effect on organizational citizenship behavior of employees, so that the hypothesis $\left(\mathrm{H}_{2}\right)$ that the work environment has a significant positive effect on organizational citizenship behavior (OCB) employees declared accepted or supported by empirical facts. The significant positive contribution of the work environment to organizational citizenship behavior of employees is due to the provision of transportation facilities, both those that use employees for operational activities and for managers who are more specialized, the provision of appropriate transportation facilities can trigger OCB employee attitudes because the facilities provided can support employees in working.

\section{Organizational citizenship behavior has a positive significant effect on employees work performance}

The results of this study prove that organizational citizenship behavior (OCB) to work performance can be proven by the standardized path coefficient (beta / standardized path coefficient) of 0.635 with a positive direction. Beta / standardized path coefficient marked positive explains that organizational citizenship behavior $(\mathrm{OCB})$ is at a high level with $\mathrm{p}$-value $=0.001<0.05$ and explains that organizational citizenship behavior (OCB) is at a high level so that it can make a significant contribution evident towards improving employee work performance. Hypothesis testing results prove that organizational citizenship behavior (OCB) has a significant positive effect on employee work performance, so that the proposed hypothesis $\left(\mathrm{H}_{3}\right)$ that organizational citizenship behavior (OCB) has a significant positive effect on the work performance of employees of the Grand Asia Hotel Makassar, which is stated to be accepted or supported by empirical facts. The positive significance of the contribution of organizational citizenship behavior (OCB) to employee work performance is due to the active participation of all activities carried out in the company so that the overall task can carry out well. In addition, there is encouragement from within employees to perform tasks better or exceed established standards so that this can trigger high employee work performance.

\section{J. Organizational support has a positive significant effect on employees work performance}

The finding of organizational support to work performance can be proven by the standardized path coefficient (beta / standardized path coefficient) of 0.215 with a positive direction. Beta / standardized path coefficient marked positive explains that organizational support is at a high level, with p-value $=0.024<0.05$ explaining that organizational support is at a high level so that it can make a 
real contribution to improving employee performance. Hypothesis testing results prove that organizational support has a significant positive effect on employee work performance, so that the hypothesis proposed $\left(\mathrm{H}_{4}\right)$ that organizational support has a significant positive effect on employee work performance Grand Asia Hotel Makassar is declared accepted or supported by empirical facts. The significant positive contribution of organizational support to employee performance is due to the company providing opportunities for employees to develop themselves. The form of development provided by the company is in the form of training provided to employees, both in the field of work being carried out and in other fields. So this can add skills and employees in performing tasks accurately so that it can indirectly improve employee work performance.

\section{$K$. Work environment has a positive significant effect on the employees work performance}

The contribution of the work environment to employee work performance can be proven by the standardized path coefficient (beta / standardized path coefficient) of 0.138 with a positive direction. Beta / standardized path coefficient marked positive explains that the work environment is at a high level but $p$-value $=0.106>0.05$ explains that even though the value of the work environment is at a high level but it cannot provide a real contribution to improving employee performance. Hypothesis testing results prove that the work environment has insignificant positive effect on employee performance, so the hypothesis $\left(\mathrm{H}_{5}\right)$ proposed that the work environment has a significant positive effect on the work performance of employees of Grand Asia Hotel Makassar, otherwise rejected or not supported by empirical facts. The positive insignificant contribution of the work environment to employee work performance is due to the fact that although the company has created a good work environment in the form of providing transportation facilities for employees, the high burden given by employees in terms of increasing the level of hotel occupancy in the past 2 years has resulted in the condition of employee psychology to decreased (non-physical work environment).

\section{Organizational support has a positive significant effect on work performance: As a mediating role of organizational citizenship behavior (OCB)}

The mediating role of organizational citizenship behavior in explaining the effect of organizational support on employee work performance is proven, it can be proved by the value of the standardized path coefficient (beta / standardized path coefficient) of 0.386 with a positive direction. Beta / standardized path coefficient marked positive explains that organizational support is at a high level with $\mathrm{p}$-value $=0.001<0.05$ explains that high organizational citizenship behavior (OCB) will support the effect of organizational support on employee work performance. These results indicate organizational citizenship behavior (OCB) as a proven mediating variable in explaining the effect of organizational support on employee work performance.
M. Work Environment has a positive significant effect on employee work performance: As a mediating role of organizational citizenship behavior (OCB) employees

The mediating role of organizational citizenship behavior in explaining the effect of the work environment on employee work performance is proven, it can be proven by the standardized path coefficient (beta / standardized path coefficient) of 0.192 with a positive direction. Beta / standardized path coefficient marked positive explains that the work environment is at a high level with p-value $=0.007$ $<0.05$ explains that high organizational citizenship behavior (OCB) will support the influence of the work environment on employee work performance. These results indicate organizational citizenship behavior (OCB) is proven as a mediating variable in explaining the influence of the work environment on employee work performance.

\section{CONCLUSION}

Organizational support is proven to be able to improve the attitude of organizational citizenship behavior of employees this is due to the provision of development in the form of training to employees in accordance with the field of work. Providing training is also carried out not only according to the field being worked on but also given training on other units of the field of work or done (cross training) so that employees have additional knowledge outside the field being worked on. This additional knowledge causes voluntary attitudes (OCB) for employees to perform tasks outside of their responsibilities in terms of helping among colleagues. Organizational support in the form of development is also proven to directly improve employee work performance.

In addition to organizational support, the work environment also has a role in enhancing the attitude of organizational citizenship behavior of employees, this is due to the provision of good transportation facilities that use employees for operational activities and for managers who are more specialized, the provision of appropriate transportation facilities can trigger OCB employee attitude because the facilities provided can support employees in working. However, even though the work environment at the Grand Asia Hotel Makassar is already good, it has not been able to improve employee work performance directly this is due to the high burden given by employees in terms of increasing the hotel occupancy rate which has decreased in the past 2 years resulting in the condition of employee psychology to decrease (non-physical work environment). In this study organizational citizenship behavior is proven to be a mediating variable in explaining the influence of organizational support and work environment on the work performance of employees of Grand Asia Hotel Makassar.

\section{REFERENCES}

[1] Wardani, WK, \& Yusrizal, F. (2017). Effect of Incentives on Employee Work Performance of Ameera Hotel Pekanbaru. Online Journal of Social and Political Sciences Faculty of Riau University Students, 4 (2), 1-10.

[2] Pratiwi, LPYA, \& Sriathi, AAA. (2017). Effect of Work Environment and Career Development on Employee Retention at Santika Hotel Nusa Dua Bali. E-Journal of Management, 6 (3), 1478-1506.

[3] Utami, H.S. (2017). The Influence of Organizational Climate on Employee Work Performance of Samarinda City Industry and Trade Office. Journal of Paradigms (JP), 2 (2), 277-289. 
[4] Rakasiwi, S., \& Wahyuning, S. (2014). Development of Information Systems for Determination of Telkom Divre Iv Employee Achievement Based on Dss Using the AHP Method. Journal of electronics and computers, 7 (2).

[5] Robert, L. Mathis. \& John H. Jackson. (2006). Human Resource Management, 10 ed., Jakarta : Salemba Four

[6] Rhoades, L., \& Eisenberger, R. (2002). Perceived organizational support: a review of the literature. Journal of applied psychology, 87(4), 698

[7] Haryadi, A., \& Connect, R. (2016). The Effect of Organizational Support on Employee Job Performance with Empowerment as an Intervening Variable. JSM (Journal of Management Science) Masters Program in Management Science UNPAR, 2302-1411

[8] Dwi Agustiningrum, Sherly. (2016). The Effect of Perception of Organizational Support on Employee Performance Mediated by OCB (Organizational Citizenship Behavior) (Study at PT. Angkasa Pura I Surabaya Branch Office). Journal of Management Science (JIM), 4 (2).

[9] Sedarmayanti, M. (2010). Bureaucratic Reform and Management of Civil Servants. Refika Aditama, Jakarta.

[10] Zuana, C.I. (2014). The Effect of Work Training and Employee Work Environment on Employee Job Performance (Study of PT. Jamsostek (Persero) Branch Malang Employees). Journal of Business Administration, 7 (1).

[11] Umboh, LW, Tewal, B., \& Adolfina, A. (2016). The Effect of Discipline, Training, Experience and Work Environment on the Work Performance of PT. Enseval Putera Mega Trading Manado. EMBA Journal: Journal of Economic, Management, Business and Accounting Research, 4 (1).

[12] Sjahruddin, H., \& Sudiro, AA. (2013). Organizational justice, organizational commitment and trust in managers as predictors of organizational citizenship behavior. Interdisciplinary J. of contemporary Res. Bus. (IJCRB), 4 (12), 133-141.

[13] Lubis, M.S. (2015). Effect of Organizational Climate and Organizational Commitment on the Formation of Organizational Citizenship Behavior (OCB) Employees in the Framework of Improving Performance. Journal of Economic Appreciation, 3 (2), 75 84.

[14] Dewanggana, BD, Paramita, P.D. \& Haryono, A.T. (2016). The Influence of Organizational Commitment, Job Satisfaction, Organizational Culture on Organizational Citizenship Behavior (OCB) that Impacts Employee Job Performance (Study at PT. PLN App Semarang). Journal of Management, 2 (2)

[15] Toban, C., \& Sjahruddin, H. (2016). The antecedent and consequence of Organizational Commitment and Job Satisfaction. Journal of Business and Management Sciences, 4(2), 26-33.

[16] Sjahruddin, H., \& Normijati, AAS. (2013). Personality effect on organizational citizenship behavior (OCB): trust in managers and organizational commitment mediators of organizational justice in Makassar City Hospitals (Indonesia). European Journal of Business and Management, 5 (9), 95-104

[17] Dewi, I.S. (2015). Effect of Satisfaction and Work Environment on Employee Performance with Organizational Citizenship Behavior as an Intervening Variable (Study of Employees at PT Indonesian Knitting Factory Semarang) (Doctoral dissertation, State University of Semarang).

[18] Indarjanti, P., \& Bodroastuti, T. (2012). Effect of Ability, Business and Organizational Support on Performance. Journal of Accounting and Business Studies, 1 (1).

[19] Kurningrum, S. (2015). Effect of Organizational Support, Job Characteristics and Organizational Justice Against Employee Engagement (At the Semarang City Regional Civil Service Agency) (Doctoral dissertation, Semarang State University).

[20] Nurhayati, D., Minarsih, MM, \& Wulan, H.S. (2016). Effect of Job Satisfaction, Work Environment and Work Loyalty on Organizational Citizenship Behavior (OCB) (Case Study at PT. Perwirabhakti Sentrase prospera in Semarang City). Journal of Management, 2 (2).

[21] Samiun, B., Sjahruddin, H., \& Purnomo, S. H. (2017). Effect Of Empowerment Of Employee Satisfaction.Organization and Management Journal.47-61. https://doi.org/10.31227/osf.io/rp8c5

[22] Sari, R. N., \& Sjahruddin, H. (2018). Effect of Competence on Employee Professional Moderated Performance. 19 30.https://doi.org/10.31227/osf.io/nw2ed

[23] Aqsariyanti, L., Sjahruddin, H. \& Razak, N. (2019). The Effect of Work Ethic and Organizational Climate on Employee Performance.27-36. https://doi.org/10.31219/osf.io/ue73v

[24] Podsakoff, P. M., MacKenzie, S. B., Paine, J. B., \& Bachrach, D. G. (2000). Organizational citizenship behaviors: A critical review of the theoretical and empirical literature and suggestions for future research. Journal of management, 26(3), 513-563.
[25] Sholihin, M., \& Ratmono, D. (2013). SEM-PLS Analysis with WarpPLS 3.0. Yogyakarta: Andi Publisher

[26] Idris, M. H., Jamali, H., \& Sjahruddin, H. (2019). Investigating the moderating role of knowledge: The relationship between auditor's experience and ethical judgment. Advances in Social Sciences Research Journal, 6(2).

[27] Bambang, P., \& Jannah, L. M. (2005). Quantitative Research Methods: Theory and Application. Jakarta: PT Raja Grafindo Persada. 
